\title{
PENINGKATAN HASIL BELAJAR TARIKH ISLAM MELALUI STRATEGI PEMBELAJARAN EVERYONE IS A TEACHER HERE PADA SISWI KELAS 2 KMI PONDOK MODERN DARUSSALAM GONTOR PUTRI
}

\author{
Ihwan Mahmudi'; Martha Laily Shofro ${ }^{2}$ \\ ${ }_{1}^{1}$ Universitas Darussalam (UNIDA) Gontor, Ponorogo/Jawa Timur, Indonesia \\ 2Pondok Modern Darussalam Gontor Putri 1, Ngawi/Jawa Timur, Indonesia \\ 1.
}

\begin{abstract}
Abstrak
Penelitian ini bertujuan untuk mengetahui peningkatan hasil belajar Tarikh Islam Siswa KMI Pondok Modern Darussalam Gontor Putri 1 menggunakan strategi pembelajaran every one is teacher here. Subjek penelitian adalah siswi KMI Gontor Putri kelas $2 \mathrm{H}$. Penelitian menggunakan jenis penelitian tindakan kelas (PTK) dengan model Kemmis dan McTaggart. Penelitian dilakukan dalam dua siklus, dan setiap siklus terdiri dari empat tahapan yaitu: perencanaan, tindakan, observasi dan refleksi. Hasil penelitian menunjukkan bahwa strategi pembelajaran Everyone Is A Teacher Here efektif meningkatkan hasil belajar Tarikh Islam siswa Kulliyyatu-lMuallimat Al-Islamiyyah Pondok Modern Darussalam Gontor Putri Kampus 1 tahun ajaran 1440-1441 H. Ketuntasan belajar siswi pada siklus pertama sebesar $46,2 \%$, meningkat pada siklus kedua menjadi 96,2\%.
\end{abstract}

Kata kunci: Everyone is a teacher here; Tarikh Islam; hasil belajar.

\begin{abstract}
This study aims to determine the increase in student achievement of Tarikh Islam, students of KMI Pondok Modern Darussalam Gontor Putri 1 using learning strategies every one is teacher here. The subject of the study was KMI Gontor for female students of Class $2 \mathrm{H}$. The study used a type of classroom action research (CAR) with the Kemmis and McTaggart models. The study was conducted in two cycles, and each cycle consisted of four stages: planning, action, observation and reflection. The results showed that Everyone Is A Teacher Here learning strategy was effective in improving the student achievement of students Kulliyyatu-l-Muallimat AlIslamiyyah Pondok Modern Darussalam Gontor Putri Campus 1 school year 1440-1441 $\mathrm{H}$. Completion of student learning in the first cycle by $46.2 \%$, increased in the second cycle to $96.2 \%$.

Keywords: Everyone is a teacher here; Tarikh Islam; student achievement.
\end{abstract}




\section{PENDAHULUAN}

Hasil belajar merupakan perubahan perilaku yang diperoleh peserta didik setelah mengalami kegiatan belajar. Hasil belajar dicapai oleh seseorang setelah melakukan kegiatan belajar yang diberikan berdasarkan atas pengukuran tertentu, sehingga diperlukan alat ukur atas pencapaian tujuan dari kegiatan pembelajaran (Lestiawan, 2018), karena hasil belajar merupakan cerminan ketercapaian kegiatan pembelajaran.

Salah satu mata pelajaran yang menjadi bagian dari Pendidikan Agama Islam (PAI) adalah Sejarah Kebudayaan Islam, yang di Pondok Modern Darussalam Gontor disebut mata pelajaran Tarikh Islam. Materi tersebut merupakan materi wajib yang di dalamnya mempelajari tentang sejarah Islam baik sebelum atau sesudah datangnya Nabi Muhammad SAW. Selain itu, ilmu pengetahuan, kepercayaan, kesenian, moral, hukum, adat-istiadat dan kemampuan yang lain serta kebiasaan yang didapat oleh manusia sebagai anggota masyarakat (Badri; 1996).

Berdasarkan hasil observasi dari Kulliyatu-l-Mualimat Al-Islamiyah nilai ujian awal tahun kelas 2 pada tahun ajaran 2017/2018 yaitu 5,06 dan pada tahun 2018/2019 yaitu 4,84. Nilai tersebut jauh dibawah KKM yang ditetapkan. Diantara penyebabnya adalah kegiatan pembelajaran di dalam kelas masih belum tercipta keterlibatan siswa secara aktif. Terlihat ada kendala dalam pembelajaran bahwa siswa hanya mendengarkan penjelasan materi dan cerita dari guru saja sehingga tidak fokus dan kurang konsentrasi.

Untuk mengatasi masalah tersebut, guru dituntut mampu memilih strategi pembelajaran yang tepat dan sesuai dengan siswa. Dengan melibatkan siswa dalam proses pembelajaran guna menciptakan kondisi pembelajaran yang aktif, salah satunya adalah Every One Is A Teacher Here. Strategi pembelajaran Every One Is A Teacher Here merupakan strategi pembelajaran yang bertujuan untuk mendapatkan partisipasi seluruh kelas dan pertanggung jawaban secara individu. Strategi pembelajaran ini memberikan kesempatan kepada setiap siswa untuk bertindak sebagai guru 
bagi siswa yang lain sehingga siswa memiliki tanggungjawab penuh atas dirinya sendiri dalam mendengarkan materi yang dijelaskan oleh guru untuk dijelaskan kembali oleh siswa dan didengarkan oleh siswa yang lain (Suryani; 2018).

Penelitian ini bertujuan untuk mengetahui peningkatan hasil belajar Peningkatan Hasil Belajar Tarikh Islam Melalui Strategi Pembelajaran Every One Is A Teacher Here Pada Siswa Kelas II di Pondok Modern Darussalam Gontor Putri Kampus 1"

\section{LANDASAN TEORI}

\section{Hasil Belajar}

Undang-undang nomor 20 tahun 2003 tentang Sistem Pendidikan Nasional, pendidikan merupakan usaha sadar dan terencana untuk mewujudkana suasana belajar dan proses pembelajaran agar peserta didik secara aktif mengembangkan potensi dirinya untuk memiliki kekuatan spiritual keagamaan, pengendalian diri, kepribadian, kecerdasan, akhlak mulia, serta keterampilan yang diperlukan dirinya, masyarakat, bangsa, dan negara. Sehingga proses pendidikan dan pembelajaran dapat dijadikan sebagai acuan bahwa siswa mengalami peningkatan dan perubahan akademis maupun non akademis ke arah yang lebih baik (Mahfud; 2014).

Menurut taksonomi Benyamin Boom mengklasifikasi hasil belajar secara garis besar dibagi menjadi tiga ranah yaitu ranah kognitif, ranah afektif dan ranah psikomotor (Arikunto; 2016). Ranah kognitif meliputi ingatan, pemahaman, aplikasi, analisis, sintesis dan evaluasi. Ranah efektif meliputi pandangan atau pendapat siswa mengenai hal-hal yang sederhana dan sikap atau nilai. Ranah psikomotorik berhubungan dengan keterampilan dan kemampuan.

Menurut Suardi dan Syofrianisda bahwa hasil belajar adalah suatu proses dimana kita dapat melihat sebuah perubahan perilaku peserta didik serta nilai evaluasi yang menjadi penentu berhasil atau tidaknya proses 
pembelajaran tersebut (Suardi dan Syofrianisda; 2018). Hasil belajar menghasilkan pola-pola perbuatan nilai-nilai, pengertian-pengertian, sikapsikap, apresiasi, dan keterampilan (Thobroni \& Mustofa; 2011).

Purwanto menyatakan bahwa hasil belajar terdiri dari dua kata, yaitu hasil dan belajar. Dan merupakan pencapaian tujuan pada seorang siswa setelah mengalami proses belajar mengajar (Purwanto; 2016). Sedang menurut Sukardi, hasil belajar ialah pencapaian perkembangan dan belajar siswa setelah menyelesaikan tugas-tugas sekolah secara tuntas (Sukardi; 2015).

Dari uraian di atas dapat diambil kesimpulan bahwa hasil belajar siswa adalah perubahan yang terdapat pada tingkah laku dan pencapaian belajar siswa yang sesuai dengan tujuan pembelajaran setelah megalami proses belajar mengajar. Dan seseorang dapat dikatakan berhasil belajar jika telah menunjukkan perubahan dalam dirinya baik dari kemampuan berfikirnya, ketrampilannya dan sikap terhadap suatu objek.

Istilah Tarikh berasal dari bahasa Arab yang artinya menurut bahasa adalah ketentuan masa. Secara istilah adalah keterangan yang menerangkan hal ihwal umat dan segala sesuatu yang telah terjadi di kalangannya pada masa yang telah lampau atau pada masa yang masih ada (cholil; 2001). Tarikh Islam merupakan suatu pengetahuan yang bermanfaat untuk mengetahui keadaan-keadaan atau kejadian-kejadian yang telah lampau dalam kehidupan umat dan keadaan-keadaan atau kejadian-kejadian yang sedang terjadi di dalam kehidupannya. Hasil belajar Tarikh Islam dalam penelitian ini adalah kemampuan peserta didik memahami peristiwaperistiwa yang terjadi dimasa lalu yang di dalamnya terkandung ilmu pengetahuan, kepercayaan, kesenian, moral, hukum, adat-istiadat dan kemampuan yang lain serta kebiasaan yang didapat oleh manusia sebagai anggota masyarakat.

Menurut Badri (1996), tujuan pembelajaran Tarikh Islam di KMI Pondok Modern Darussalam Gontor adalah: 
1. Siswa mengetahui kemajuan dan kemunduran bangsa yang menganut Islam dan sebab-sebabnya.

2. Siswa mengetahui pahlawan-pahlawan dan tokoh-tokoh yang telah berjasa dalam menyiarkan agama Islam agar dapat mencontoh mereka.

3. Siswa mengetahui masyarakat Islam yang adil dan makmur yang telah dibina oleh Nabi Muhammad SAW, sahabat-sahabatnya dan khulafau-r-rasyidin.

4. Siswa dapat mengambil pelajaran dan teladan dari kemajuan atau kemundiuran itu untuk masa depan.

\section{Strategi Pembelajaran Every One Is A Teacher Here}

Strategi pembelajaran merupakan suatu perencanaan atau pola yang digunakan sebagai pedoman dalam merencanakan pembelajaran di kelas atau pembelajaran tutorial. Strategi pembelajaran tersebut juga sangat mempengaruhi keberhasilan guru dalam proses belajar mengajar. Maka guru harus pintar dalam memilih strategi pembelajaran yang akan diterapkan dalam proses belajar mengajar sehingga tujuan pembelajaran dapat tercapai. Dan siswa akan mendapatkan hasil belajar yang positif (Afandi; 2013).

Dalam pemilihan strategi pembelajaran guru harus melibatkan siswa dalam proses pembelajaran guna menciptakan kondisi pembelajaran yang aktif. Salah satunya dengan strategi pembelajaran aktif dimana siswa aktif dalam menyampaikan pendapat, atau gagasan dan belajar secara berkelompok (Zuliani; 2017).

Strategi pembelajaran Everyone Is A Teacher Here merupakan strategi pembelajaran yang betujuan untuk mendapatkan partisispasi seluruh kelas dan pertanggung jawaban individu. Sehingga setiap siswa berkesempatan untuk bertindak sebagai guru bagi siswa yang lain. Jika seorang guru ingin menciptakan kelas yang kondusif dimana siswa juga turut berperan aktif, 
maka strategi pembelajran ini sangat cocok digunakan demi menciptakan kelas yang kondusif (Suryani: 2018).

Strategi Everyone Is A Teacher Here memberikan pemahaman kepada para peserta didik bahwa guru bukanlah satu-satunya sumber ilmu pengetahuan. Dalam hal ini, pengetahuan dapat juga diperoleh dari teman sebaya sehingga setiap peserta didik memiliki kesempatan berbagi informasi dengan rekannya sesuai kemampuan masing-masing (Hidayat; 2019).

Adapun langkah-langkah penerapan strategi pembelajaran Every one Is A Teacher Here adalah sebagai berikut (Hidayat; 2019):

1. Bagikan secarik kertas keseluruh siswa, setiap siswa diminta menuliskan suatu pertanyaan-pertanyaan tentang materi pelajaran yang sedang dipelajari dikelas.

2. Kumpulkan kertas, acak kertas tersebut, kemudian bagikan kepada setiap siswa. Pastikan bahwa tidak ada siswa yang menerima soal yang ditulis sendiri. Minta mereka untuk membaca dalam hati pertanyaan dalam kertas tersebut kemudian memikirkan jawabannya.

3. Mintalah siswa secara sukarela untuk membacakan pertanyaan tersebut dan menjawabnya.

4. Setelah jawaban diberikan, mintalah siswa lain untuk menambahkannya.

5. Lanjutkan dengan siswa sukarela atau guru yang menunjuk siswa untuk membacakan pertanyaan dan menjawabnya sampai pertanyaan terjawab semua.

Kelebihan strategi pembelajaran ini bagi peserta didik antara lain sebagai berikut (Hidayat; 2019):

1. Pertanyaan-pertanyaan yang diajukan dapat menarik dan memusatkan perhatian

2. Melatih daya pikir dan daya ingat

3. Mengembangkan keberanian dan keterampilan menyampaikan pendapat 


\section{METODE}

Penelitian ini dilakukan di Pondok Modern Darussalam Gontor Putri Kampus 1 Mantingan Ngawi Jawa Timur Indonesia. Subjek penelitian adalah siswi KMI Gontor Putri kelas 2 H. Penelitian menggunakan jenis penelitian tindakan kelas (PTK) dengan model Kemmis dan McTaggart. Model ini terdiri dari empat tahapan yang ada di dalam satu siklus, yaitu: perencanaan, tindakan, observasi dan refleksi (Muallimin; 2014). Penelitian dilaksanakan dalam dua siklus dimana setiap siklus dilaksanakan dua atau tiga kali pertemun. Model penelitian ini adalah seperti gambar berikut:

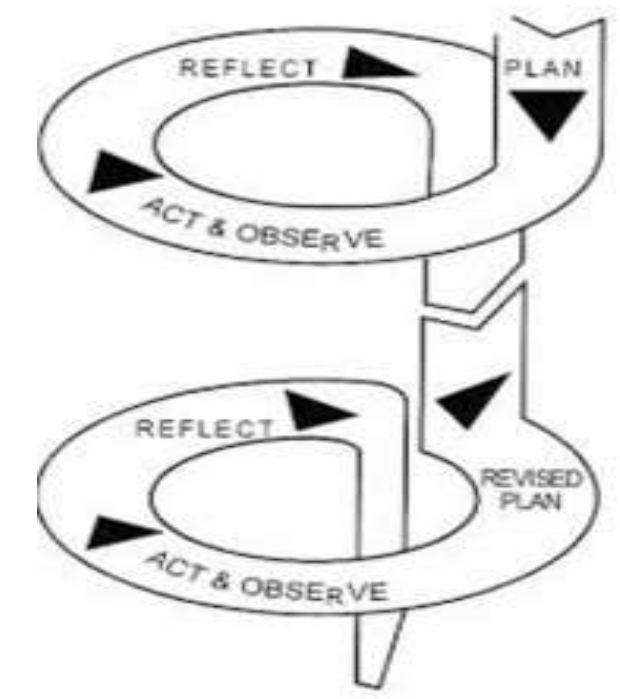

Gambar 1. PTK Model Kemmis dan McTaggart

Data penelitian ini terdiri dari nilai Mata Pelajaran Tarikh Islam dan kegiatan siswa selama proses pembelajaran. Pengumpulan data menggunakan tes, observasi, dan wawancara. Analisis data dilakukan menggunakan analisis deskriptif.

\section{HASIL DAN PEMBAHASAN}

Penelitian ini terdiri dari dua siklus. Data nilai hasil belajar tarikh islam siswa pada penelitian ini adalah sebagai berikut: 
Tabel 1. Data Hasil Belajar Siklus 1 dan Siklus 2

\begin{tabular}{clccclccc}
\hline \multirow{2}{*}{ No. } & \multirow{2}{*}{ Nama } & \multicolumn{2}{c}{ Nilai } & \multirow{2}{*}{ No. } & \multirow{2}{*}{ Nama } & \multicolumn{2}{c}{ Nilai } \\
& & Siklus 1 & Siklus 2 & & & 6 & Siklus 1 & Siklus 2 \\
\hline 1 & F.N & 4 & 7 & 14 & D.F & 6 & 7 \\
2 & A.A.M & 7 & 9 & 15 & F.A.S & 4 & 8 \\
3 & T.Z & 6 & 9 & 16 & S.M & 5 & 8 \\
4 & R.R.N & 7 & 8 & 17 & Q.B & 3 & 8 \\
5 & N.I.M & 6 & 7 & 18 & S.N.H & 5 & 8 \\
6 & M.S & 6 & 9 & 19 & H.N.F & 2 & 7 \\
7 & N.I & 3 & 9 & 20 & A.S.K.P & 3 & 6 \\
8 & A.A.K & 4 & 5 & 21 & N.Z.S & 3 & 7 \\
9 & N.A.Y & 5 & 9 & 22 & M.P & 3 & 9 \\
10 & A.R.H & 4 & 9 & 23 & S.D.P & 6 & 9 \\
11 & N.A & 8 & 9 & 24 & S.Q & 4 & 7 \\
12 & L.K & 3 & 8 & 25 & F.A. & 3 & 5 \\
13 & A.N.R & 5 & 8 & 26 & J.N.K & 4 & 4 \\
\hline
\end{tabular}

Data nilai hasil belajar tersebut, dianalisa secara deskriptif sebagai berikut:

\section{Siklus I}

Data hasil belajar siswa pada siklus 1 disajikan dalam tabel analisis deskriptif sebagai berikut:

Tabel 2. Analisis Deskriptif Siklus_1

\begin{tabular}{lrr}
\hline $\mathrm{N}$ & Valid & 26 \\
& Missing & 0 \\
\hline Mean & 4.58 \\
Median & 4.00 \\
Mode & 3 \\
Range & 6 \\
Minimum & 2 \\
Maximum & 8 \\
Sum & 119 \\
\hline
\end{tabular}

Dari data Penelitian Tindakan Kelas siklus pertama diatas menunjukkan bahwa Mean atau rata-rata hasil belajar Tarikh Islam kelas $2 \mathrm{H}$ melalui strategi pembelajaran aktif Everyone Is A Teacher Here adalah 4,58. Nilai 
median sebesar 4,00 dalam arti bahwa 50\% sampel mempunyai hasil belajar Tarikh Islam 4,00 ke atas dan 50\% mempunyai hasil belajar Tarikh Islam 4,00 ke bawah dengan modus atau data hasil belajar Tarikh Islam dengan frekuensi terbanyak adalah 3. Dari tabel di atas didapatkan bahwa hasil belajar Tarikh Islam kelas $2 \mathrm{H}$ ada siklus pertama dengan nilai minimun 2 dan nilai maksimum 8 , sehingga range yaitu $(8-2)=6$. Dengan total hasil belajar Tarikh Islam keseluruhan yaitu 119.

Tabel 3. Frekuensi Data Hasil Belajar Tarikh Islam Siklus I

\begin{tabular}{llrrrr}
\hline & & Frequency & Percent & Valid Percent & \multicolumn{2}{c}{$\begin{array}{c}\text { Cumulative } \\
\text { Percent }\end{array}$} \\
\hline Valid & 2 & 1 & 3.8 & 3.8 & 3.8 \\
& & 7 & 26.9 & 26.9 & 30.8 \\
& & 6 & 23.1 & 23.1 & 53.8 \\
& 4 & 4 & 15.4 & 15.4 & 69.2 \\
& 5 & 19.2 & 19.2 & 88.5 \\
6 & 2 & 7.7 & 7.7 & 96.2 \\
7 & 1 & 3.8 & 3.8 & 100.0 \\
\hline & 26 & 100.0 & 100.0 & \\
\hline
\end{tabular}

Dari tabel di atas dijelaskan bahwa hasil belajar Tarikh Islam dengan perolehan nilai 2 sebanyak 1 siswi dengan presentase 3,8\%, nilai 3 sebanyak 7 siswi dengan presentase 26,9\%, nilai 4 sebanyak 6 siswi dengan presentase 23,1\%, nilai 5 sebanyak 4 siswi dengan presentase 15,4\%, nilai 6 sebanyak 5 siswi dengan presentase 19,2\%, nilai 7 sebanyak 2 siswi dengan presentase 7,7\% dan nilai 8 sebanyak 1 siswi dengan presentase 3,8\%. Dapat diketahui siswi yang nilainya berada di bawah KKM 4,80 sejumlah 14 siswi dengan presentase 53,8\% dan siswi yang nilainya berada di atas KKM yaitu 12 siswi dengan presentase $46,2 \%$. 


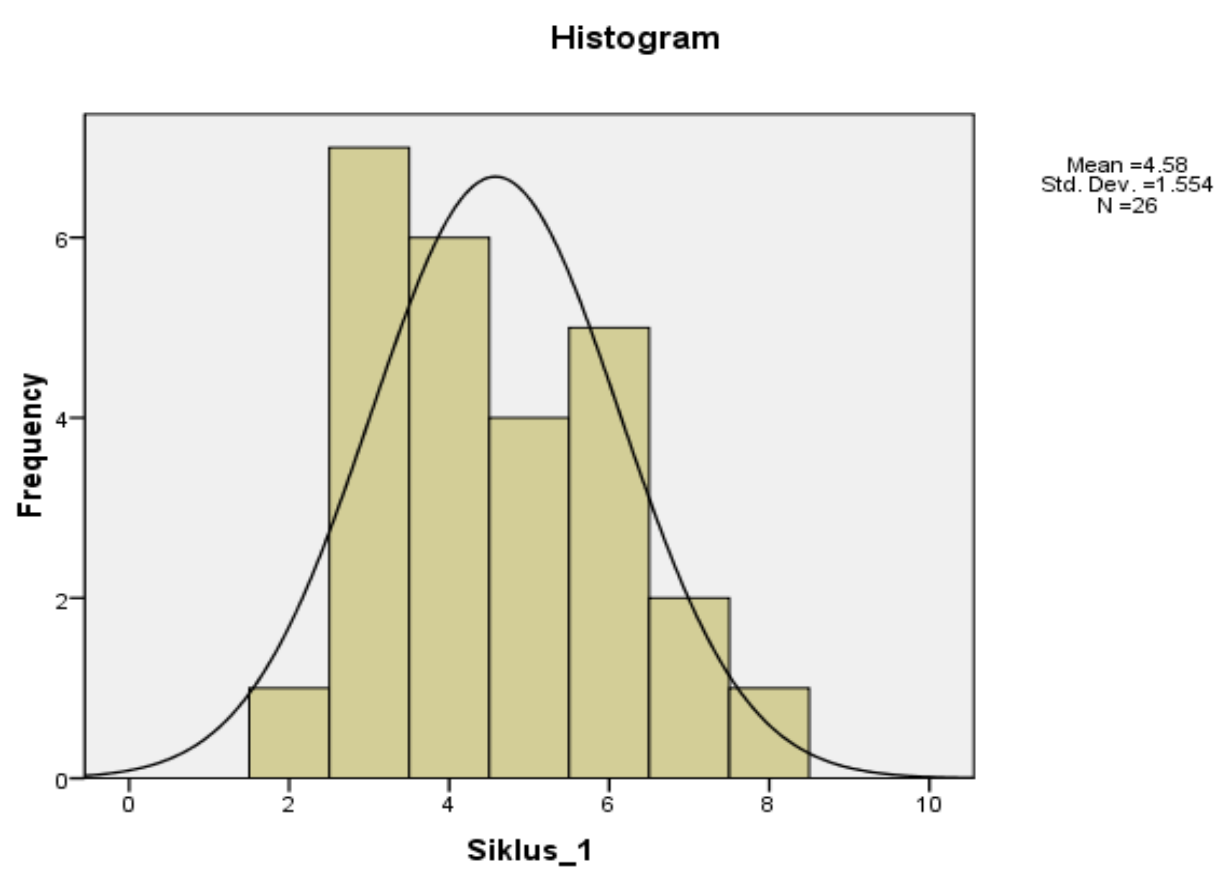

Gambar 2. Histogram Hasil Belajar Tarikh Islam Siklus I

\section{Siklus II}

Data hasil belajar siswa pada siklus 2 disajikan dalam tabel analisis deskriptif sebagai berikut:

Tabel 4. Analisis Data Hasil Belajar Siklus II

\begin{tabular}{llr}
\hline $\mathrm{N}$ & Valid & 26 \\
& Missing & 0 \\
\hline Mean & & 7.65 \\
Median & 8.00 \\
Mode & 9 \\
Range & 5 \\
Minimum & 4 \\
Maximum & 9 \\
Sum & 199 \\
\hline
\end{tabular}

Dari data Penelitian Tindakan Kelas siklus kedua diatas menunjukkan bahwa Mean atau rata-rata hasil belajar Tarikh Islam kelas $2 \mathrm{H}$ melalui strategi pembelajaran aktif Everyone Is A Teacher Here adalah 7,65. Nilai 
median sebesar 8,00 dalam arti bahwa 50\% sampel mempunyai hasil belajar Tarikh Islam 8,00 ke atas dan 50\% mempunyai hasil belajar Tarikh Islam 8,00 ke bawah dengan modus atau data hasil belajar Tarikh Islam dengan frekuensi terbanyak adalah 9. Dari tabel di atas didapatkan bahwa hasil beljar Tarikh Islam kelas $2 \mathrm{H}$ pada siklus kedua dengan nilai minimun 4 dan nilai maksimum 9, sehingga range yaitu $(9-4)=5$. Dengan total hasil belajar Tarikh Islam keseluruhan yaitu 199.

Tabel 5. Frekuensi Data Hasil Belajar Tarikh Islam Siklus II

\begin{tabular}{llrrrr}
\hline & & Frequency & Percent & Valid Percent & \multicolumn{2}{c}{$\begin{array}{c}\text { Cumulative } \\
\text { Percent }\end{array}$} \\
\hline Valid & 4 & 1 & 3.8 & 3.8 & 3.8 \\
& 5 & 2 & 7.7 & 7.7 & 11.5 \\
& 6 & 1 & 3.8 & 3.8 & 15.4 \\
& 6 & 23.1 & 23.1 & 38.5 \\
& 6 & 7 & 26.9 & 26.9 & 65.4 \\
& 9 & 34.6 & 34.6 & 100.0 \\
\hline & & 26 & 100.0 & 100.0 & \\
\hline
\end{tabular}

Dari tabel di atas dijelaskan bahwa hasil belajar Tarikh Islam dengan perolehan nilai 4 sebanyak 1 siswi dengan presentase 3,8\%, nilai 5 sebanyak 2 siswi dengan presentase 7,7\%, nilai 6 sebanyak 1 siswi dengan presentase 3,8\%, nilai 7 sebanyak 6 siswi dengan presentase 23,1\%, nilai 8 sebanyak 7 siswi dengan presentase 26,9\% dan nilai 9 sebanyak 9 siswi dengan presentase 34,6\%. Dapat diketahui siswi yang nilainya berada di bawah KKM 4,80 sejumlah 1 siswi dengan presentase 3,8\% dan siswi yang nilainya berada di atas KKM yaitu 25 siswi dengan presentase 96,2\%. 


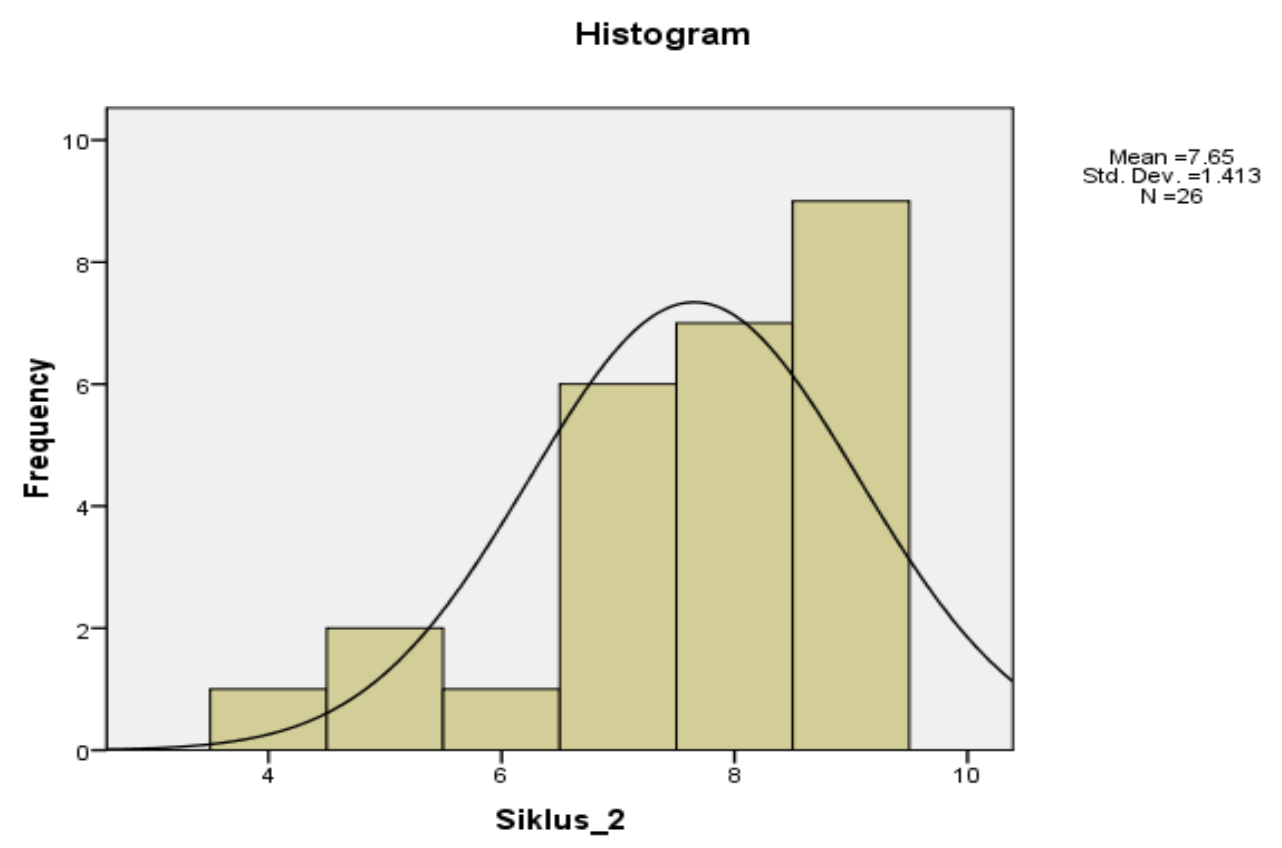

Gambar 3. Histogram Hasil Belajar Tarikh Islam Siklus II

\section{Perbandingan Hasil Belajar Tarikh Islam Siklus I dan II}

Dari data Penelitian Tindakan Kelas siklus pertama dan kedua di atas menunjukkan bahwa Mean atau rata-rata hasil belajar Tarikh Islam kelas $2 \mathrm{H}$ melalui strategi pembelajaran aktif Everyone Is A Teacher Here pada siklus pertama adalah 4,58 dan pada siklus kedua adalah 7,65. Nilai median pada siklus pertama sebesar 4,00 dalam arti bahwa 50\% sampel mempunyai hasil belajar Tarikh Islam 4,00 ke atas dan 50\% mempunyai hasil belajar Tarikh Islam 4,00 ke bawah, sedangkan pada siklus kedua sebesar 8,00 dalam arti bahwa 50\% sampel mempunyai hasil belajar Tarikh Islam 8,00 ke atas dan 50\% mempunyai hasil belajar Tarikh Islam 8,00 ke bawah. Modus atau data hasil belajar Tarikh Islam dengan frekuensi terbanyak pada siklus pertama adalah 3 dan pada siklus kedua adalah 9. Dari tabel di atas didapatkan bahwa hasil beljar Tarikh Islam kelas $2 \mathrm{H}$ pada siklus pertama dengan nilai minimun 2 dan nilai maksimum 8, sehingga range yaitu (8-2) = 6 sedangkan pada siklus kedua dengan nilai minimun 4 dan nilai maksimum 9, sehingga range yaitu $(9-4)=5$. Dengan total hasil belajar Tarikh Islam keseluruhan pada 
siklus pertama adalah 119 dan pada siklus kedua adalah 199. Dengan data tersebut maka hasil belajar Tarikh Islam kelas $2 \mathrm{H}$ meningkat dengan presentase ketuntasan sebagai berikut:

Tabel 6. Presentase Ketuntasan Hasil Belajar Siklus I dan II

\begin{tabular}{cccccc}
\hline \multirow{2}{*}{ No. } & \multirow{2}{*}{ Siklus } & \multicolumn{2}{c}{ Tuntas } & \multicolumn{2}{c}{ Tidak Tuntas } \\
\cline { 3 - 6 } & & $\begin{array}{c}\text { Jumlah } \\
\text { Siswa }\end{array}$ & Presentase & $\begin{array}{c}\text { Jumlah } \\
\text { Siswa }\end{array}$ & Presentase \\
\hline 1 & Siklus I & 12 & $46,2 \%$ & 14 & $53,8 \%$ \\
2 & Siklus II & 25 & $96,2 \%$ & 1 & $3,8 \%$ \\
\hline
\end{tabular}

Untuk melihat perbandingan nilai dari kedua siklus tersebut, disajikan gambar sebagai berikut:

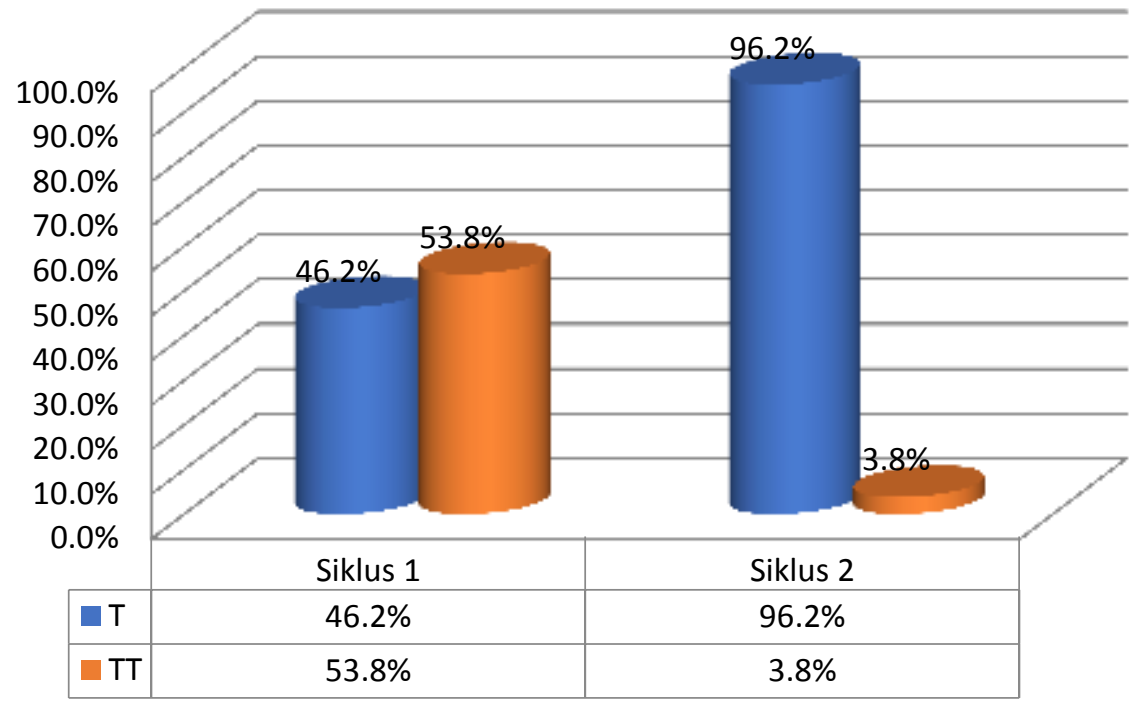

Gambar 4. Diagram Presentase Ketuntasan Hasil Belajar Siklus I dan II

Dari data di atas dijelaskan dari 26 siswa yang mencapai tingkat ketuntasan hasil belajar Tarikh Islam melalui strategi pembelajaran Everyone Is A Teacher Here pada siklus pertama yaitu 12 siswa dengan presentase 46,2\% dan pada siklus kedua yaitu 25 siswa dengan presentase 96,2\%. 
Sedangkan siswa yang tidak mencapai tingkat ketuntasan pada siklus pertama yaitu 14 siswi dengan presentase 53,8\% dan pada siklus kedua 1 orang dengan presentase 3,8\%.

Hasil penelitian ini secara umum menunjukkan bahwa strategi pembelajaran Everyone Is A Teacher Here cukup efektif untuk meningkatkan hasil belajar Tarikh Islam kelas 2H Kulliyyatu-l-Muallimat Al-Islamiyyah di Pondok Modern Darussalam Gontor Putri Kampus 1. Hal tersebut dapat dilihat dari tabel data berikut:

Tabel 7. Data Hasil Belajar Tarikh Islam Siklus I dan II

\begin{tabular}{cccc}
\hline No. & Keterangan & Siklus 1 & Siklus 2 \\
\hline 1 & Jumlah Nilai & 119 & 199 \\
2 & Rata-Rata & 4,58 & 7,65 \\
3 & Tuntas & $46,2 \%$ & $96,2 \%$ \\
4 & Tidak Tuntas & $53,8 \%$ & $3,8 \%$ \\
5 & Keaktifan Siswi & $81,25 \%$ & $96,85 \%$ \\
\hline
\end{tabular}

Dari data diatas dapat dilihat bahwa hasil belajar Tarikh Islam kelas $2 \mathrm{H}$ melalui strategi pembelajaran Everyone Is A Teacher Here mengalami peningkatan dengan bukti bahwa pada siklus pertama jumlah nilai keseluruhan adalah 119 dan pada siklus kedua adalah 199. Nilai rata-rata pada siklus pertama 4,58 dan siklus kedua 7,65. Tingkat ketuntasan hasil belajar pada siklus pertama adalah 46,2\% dan siklus kedua adalah 96,2\% sedangkan siswi yang tidak tuntas atau di bawah KKM pada siklus pertama adalah 53,8\% dan siklus kedua adalah 3,8\%. Keaktifan siswi juga mengalami peningkatan pada siklus pertama adalah $81,25 \%$ dan siklus kedua adalah $96,85 \%$. 


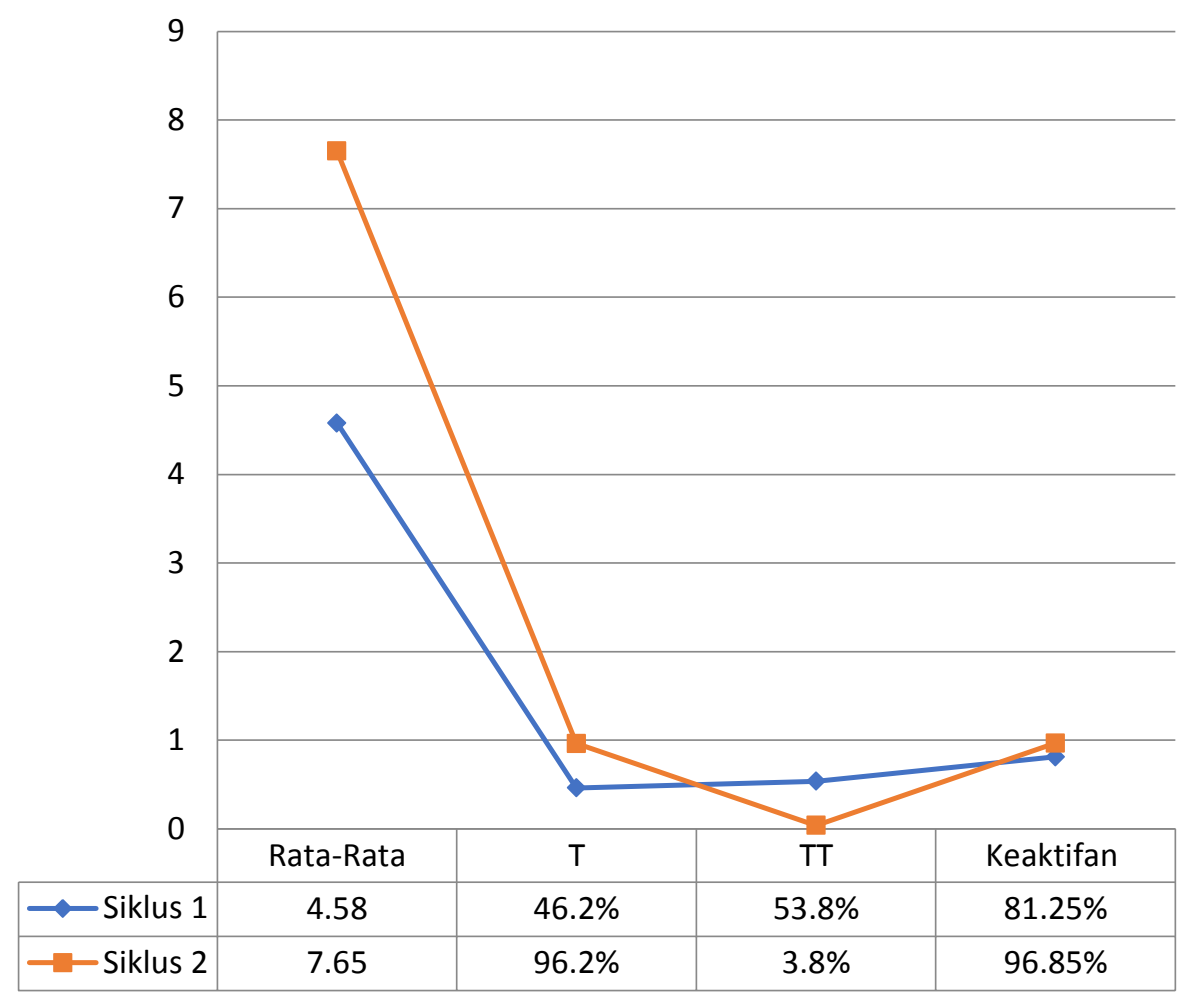

Gambar 5. Peningkatan Hasil Belajar Tarikh Islam Siklus I dan II

\section{KESIMPULAN}

Penerapan strategi pembelajaran Everyone Is A Teacher Here efektif meningkatkan hasil belajar Tarikh Islam kelas 2H Kulliyyatu-l-Muallimat AlIslamiyyah di Pondok Modern Darussalam Gontor Putri Kampus 1 tahun ajaran 1440-1441 H. Hasil penelitian menunjukkan pada siklus pertama siswi yang mencapai tingkat ketuntasan sebesar $46,2 \%$ dari 26 siswi dan siswi yang belum tuntas sebesar 53,8\% dari 26 siswi. Sedangkan pada siklus kedua siswi yang mencapai tingkat ketuntasan sebesar 96,2\% dari 26 siswi dan siswi yang belum tuntas sebesar 3,8\% dari 26 siswi.

\section{DAFTAR PUSTAKA}

Afandi, Muhammad. Chamalah, Evi.et al. 2013. Model dan Metode Pembelajaran di Sekolah. Semarang: UNISSULA Press. 
Mahmudi, I., \& Shofro, M. L. (2019). PENINGKATAN HASIL BELAJAR TARIKH ISLAM MELALUI STRATEGI PEMBELAJARAN EVERYONE IS A TEACHER HERE PADA SISWI KELAS 2 KMI PONDOK MODERN DARUSSALAM GONTOR PUTRI. Jurnal Tatsqif, 17(2), 171-186. https://doi.org/10.20414/itq.v17i2.1962

Arikunto, Suharsimi. 2016. Dasar-Dasar Evaluasi Pendidikan Edisi 2. Jakarta: Bumi Aksara.

Badri, Imam. 1996. Diktat Penataran Guru Kulliyatu-l-Muallimat Al-Islamiyah Pondok Modern Darussalam Gontor Putri. Ponorogo: PGB Press.

Cholil, Moenawar. 2001. Kelengkapan Tarikh Nabi Muhammad SAW. Jilid 1. Jakarta: Gema Insani.

Hidayat, Isnu. 2019. 50 Strategi Pembelajaran Populer. Yogyakarta: Diva Press.

Lestiawan, Fendi. dan Johan, Arif Bintoro. 2018. Penerapan Metode Pembelajaran Example Non Example Untuk Meningkatkan Keaktifan dan Hasil Belajar Dasar-Dasar Pemesinan. Jurnal Taman Vokasi. Vol. 6. No. 1.

Mahfud. 2014. Optimalisasi Pembelajaran IPS Pada Siswa Kelas VI Melalui Metode Contextual Teaching Learning (CTL). Pedagodia. Vol. 3. No. 2.

Mualimin. 2014. Penelitian Tindakan Kelas Teori dan Praktik. Pasuruan: Gending Pustaka.

Purwanto. 2016. Evaluasi Hasil Belajar. Yogyakarta: Pustaka Pelajar.

Suardi, Moh dan Syofrianisda. 2018. Belajar dan Pembelajaran. Yogyakarta: Parama Ilmu.

Sukardi. 2015. Evaluasi Pendidikan (Prinsip dan Operasionalnya). Jakarta: Bumi Aksara.

Suryani. 2018. Every One Is A Teacher Here: Peningkatan Prestasi Belajar Mata Pelajaran IPA Kelas IV SD. Jurnal Pendidikan: Riset dan Konseptual. Vol. 2. No. 3.

Thobroni, Muhammad dan Mustofa, Arif. 2011. Belajar dan Pembelajaran, Yogyakarta: Ar-Ruzz Media.

Zuliani, Putri. dan Habibati, M. Nasir. 2017. Penerapan Model Pembelajaran Every One Is a Teachere Here Untuk Meningkatkan Aktivitas Dan Hasil Belajar Kimia Koloid Siswa Kelas XI IA di SMA Negeri 5 Banda Aceh. Jurnal Ilmiah Mahasiswa Pendidikan Kimia. Vol. 2. No. 1. 